\title{
Eualuating the psychometric properties of a Malay version of Bostick's (1992) Library Anxiety scale
}

\author{
Noor Harun Abdul Karim ${ }^{1 *}$ and Noor Rashidalila Ab Rashid ${ }^{2}$ \\ ${ }^{1}$ Department of Library and Information Science, \\ Faculty of Computer Science and Information Technology, \\ University of Malaya, Kuala Lumpur, MALAYSIA \\ ${ }^{2}$ Saito College, Petaling Jaya, Selangor, MALAYSIA \\ e-mail: *nharun@um.edu.my (corresponding author); \\ noor.rashidalila@saito-college.edu.my
}

\begin{abstract}
The purpose of this study was to identify the components of library anxiety using a Malay version of Bostick's (1992) Library Anxiety Scale (LAS) and to examine the effects of demographic variables such as gender, native language, year of study, prior exposure to library services and medium of instruction on the variation in the library anxiety construct. A 46-item Malay version of Bostick's (1992) Library Anxiety Scale (LAS) was tested among 130 medical students drawn randomly from a population of 423 students pursuing their Bachelor of Medicine or Bachelor of Surgery (MBBS) degree. The findings revealed a 3-factor solution which corresponded to the five factors as found by Bostick's (1992) pioneering psychometric measure of library anxiety. The sub-scales of library anxiety were termed barriers with staff, affective barriers and comfort with library technology. The factor barriers with staff explained $19.76 \%$ of the variance in the library construct, followed by affective barriers factor explaining $11.55 \%$ of the variance and a third factor comfort with library technology explained $10.282 \%$ of the variance. The overall scale as well as each of the three sub-scales was submitted to an internal reliability assessment resulting in a satisfactory Cronbach's internal reliability coefficient alpha. Despite the fewer number of sub-scales that were yielded by the Malay version of Bostick's (1992) Library Anxiety Scale (LAS), the translated scale has been shown to be a valid and reliable instrument.
\end{abstract}

Keywords: Library anxiety; Medical students; Construct validity; Internal reliability; Bostick's Library Anxiety Scale

\section{INTRODUCTION}

'Anxiety' is manifested in the form of a feeling of uneasiness, worry, nervousness and apprehension experienced when people are faced with challenges. Library anxiety is defined as library user's feeling of discomfort, uneasiness, uncertainty, fear and nervousness when he or she is confronted with the task of using the library in order to complete course related assignments. In academic circles, library anxiety occurs when students are not sure of how to use the library resources and services. They are more likely to pretend to know everything rather than ask the library staff for help. Jiao, Onwuegbuzie and Bostick (2004) noted that library anxiety may occur from a lack of confidence while doing the research in the library or lack of exposure to library facilities and services. It 
clearly shows that students with inadequate exposure of the library are more likely to be anxious when using it. In addition, Anwar, Al-Kandari and Al-Qallaf (2004), observed that library anxiety can clearly be defined as a psychological barrier to academic success and achievement among students that hinders the optimal use of library systems, services, and resources by its patrons. Mellon (1986) was the first to introduce the concept of library anxiety. Her study revealed several reasons to explain why this library anxiety phenomenon was happening: not familiar with layout of the library, lack of knowledge about where the resources are located, how to use and what to do, overwhelmed by the library, feelings of inadequacy and hesitancy to approach the library staff for any type of enquiries. The Library Anxiety Scale (LAS) was developed and validated by Sharon L Bostick in her doctoral dissertation study (Bostick 1992). Using exploratory factor analysis, Bostick developed the Library Anxiety Scale (LAS) which comprise five sub-scales: (a) barriers with staff; (b) affective barriers; (c) comfort with the library; (d) knowledge of the library; (e) mechanical barriers.

Barriers with staff refer to the students' perception that librarians, as well as other library employees, are unapproachable or too busy to assist them (Jiao and Onwuegbuzie 1999a; Mellon 1986). A high score on this sub-scale or dimension will indicate higher levels of library anxiety. Affective barriers relates to students feeling inadequate about their abilities to effectively use the library (Jiao and Onwuegbuzie 1999z). A high score on this sub-scale will indicate greater levels of library anxiety. Comfort with the library relates to students' reactions to the ambiance of the library. If students do not feel the library is welcoming and non-threatening, they are unlikely to feel at ease to use the library effectively (Jiao and Onwuegbuzie, 1999a; Jiao, Onwuegbuzie and Lichtenstein 1996). A high score on this subscale will indicate lesser levels of library anxiety whereas lower scores will indicate greater levels of library anxiety. Knowledge of the library relates to students' perceptions of familiarity they have of the library (Jiao and Onwuegbuzie 1999a). A high score on this subscale will indicate low anxiety whereas low score will indicate higher levels of library anxiety. Mechanical barriers refers to students' reliance on mechanical library equipment, including change machines, computer printers, etc. (Jiao and Onwuegbuzie 1999a). A high score on this sub-scale will indicate higher levels of library anxiety.

While a number of studies were conducted out to validate the Library Anxiety Scale (LAS), little effort was done to translate the scale into another language and to subsequently test the translated version of that scale. Shoham and Mizrachi (2001) employed a Hebrew version of Library Anxiety Scale (LAS). However, no attempt was made to report the psychometric properties of the scale. This study employed a Malay language version of Bostick's (1992) Library Anxiety Scale (LAS) and subsequently tested the psychometric properties of the translated version of Bostick's Library Anxiety Scale (LAS). The study was able to cross-culturally demonstrate the scale applicability among a population where the native language is not English.

\section{LITERATURE REVIEW}

The review of related literature would include studies conducted on library anxiety using the various psychometric instruments available to the researcher. Many of these studies employed either a modified version of Bostick's (1992) Library Anxiety Scale or a translated version of the aforesaid scale. This review would examine some of these modified and translated versions of Bostick's (1992) Library Anxiety Scale: Shoham and Mizrachi (2001); 
Van Kampen (2004); Anwar, Al-Kandari and Al-Qallaf (2004); Noor and Ansari (2010); Swigon (2011).

Bostick (1992) developed and validated the Library Anxiety Scale. This 43-item 5-point Likert-type scale instrument has five dimensions, namely, barriers with staff, ( $\alpha=0.90)$; affective barriers, $(\alpha=0.80)$; comfort with the library, $(\alpha=0.66)$; knowledge of the library, $(\alpha=0.62)$; and mechanical barriers, $(\alpha=0.60)$. These factors collectively explained $51.8 \%$ of the variation in library anxiety. Further, the internal reliability assessment using Cronbach's internal reliability coefficient alpha $\alpha$ was reported to be at 0.80 for the overall scale. A test-retest further confirmed the overall scale to be internally reliable at 0.74 . This instrument has been utilized extensively in a number of library anxiety studies.

Shoham and Mizrachi (2001) investigated the library anxiety phenomenon among undergraduate students in Israel. They however employed a modified Hebrew version of Bostick's (1992) which was referred to as the H-LAS. The H-LAS is a 35-item library anxiety scale which when tested for construct validity using exploratory factor analysis resulted in a seven factor solution with the following sub-scales: staff factor, knowledge factor, language factor, physical comfort factor, library computer comfort factor, library policies/hours factor and resource factor. Shoham and Mizrachi (2001) did not provide information about the percentage of total variance explained by all the factors. The subscales when examined for internal reliability estimates were found to have the following alpha reliability coefficients: staff factor, 0.75 ; knowledge factor, 0.76 ; language factor, 0.76; physical comfort factor, 0.60 ; library computer comfort, 0.51 ; library policies/hours factor, 0.45 ; resource factor, 0.52

Van Kampen (2004) developed a multi-dimensional 53-item instrument to measure library anxiety. The instrument was administered to 554 doctoral students at an urban university in south eastern United States of America. Results of running an exploratory factor analysis yielded six factors which collectively explained $43.39 \%$ of the variance. Further, the six factors were found to have the following Cronbach's alpha reliability coefficients: barriers with staff, 0.73; comfort and confidence when using the library, 0.86; comfort level while inside the library building, 0.74 ; comfort level with technology as it applies to the library, 0.73 ; importance of understanding how to use the library, 0.79 ; information search process and general library anxiety, 0.87 .

Anwar, Al-Kandari and Al-Qallaf (2004) investigated the library anxiety phenomenon among 145 undergraduate biological sciences students in Kuwait. The 34-item instrument was based on the Library Anxiety Scale developed by Bostick (1992). Exploratory factor analysis was used to determine the appropriate number of factors and statement groupings in each of these factors. The factor analysis yielded four (4) factors, which explained $47 \%$ of the total variance. The four factors were found to have the following Cronbach's alpha reliability coefficients: Staff approachability, 0.91; Feelings of inadequacy, 0.79; Library confidence, 0.78 ; Library constraints, 0.71 .

Noor and Ansari (2010) administered a 49-item modified version of Bostick's (1992) Library Anxiety Scale to 367 undergraduate students in a Malaysian institution of higher learning. The instruments were administered during classroom hours using a self-reported questionnaire. This study attempted to evaluate the scale's psychometric soundness and stability among a population whose native language is not English. Results of running an exploratory factor analysis yielded five factors which collectively explained $39.56 \%$ of the variance. The sub-scales when examined for internal reliability estimates were found to 
have the following alpha reliability coefficients: barriers with staff, 0.91 ; comfort with library services, 0.73 ; affective barriers, 0.70 ; cognitive barriers, 0.81 ; comfort with library technology, 0.68 .

Swigon (2011) developed the Polish Library Anxiety Scale (P-LAS) which based on Bostick's Library Anxiety Scale (LAS) and three other scales: Multidimensional LAS (MLAS), HebrewLAS (H-LAS), and Kuwait-LAS (KLAS). The instrument was administered to 100 participants comprising bachelor's level students, master's level students, doctoral level students, and faculty members at three Polish universities were studied. This 46-item library anxiety scale which when tested for construct validity using exploratory factor analysis resulted in a six factor solution with the following sub-scales: barriers with staff, $(\alpha=0.75)$; affective barriers, $(\alpha=0.80)$; technological barriers, $(\alpha=0.73)$; library knowledge barriers, $(\alpha=0.78)$; library comfort barriers, $(\alpha=0.47)$ and resources barriers, $(\alpha=0.75)$.

While much psychometric efforts have been expended to test and validate Bostick's (1992) LAS, very little empirical effort has been attempted to validate the LAS's psychometric properties in a language other than English (Shoham and Mizrachi 2001). Much of the empirical efforts have been carried out to test several modified versions of the scale's psychometric properties. Herein lies our attempt to fill in the empirical gap in the sub-field of library anxiety among non-native speakers of English by using a local language version of the scale.

\section{METHODOLOGY}

This study employed a cross sectional correlational survey design for collecting data from respondents. For the purpose of this research, a self-reported questionnaire was designed to obtain data from the respondents. The questionnaire was divided into three sections. Section 1 elicits demographic information such as gender, nationality, native language and year of study. Section 2 elicits information on frequency of library visit, physical distance from library, previous library experience and prior medium of library instruction. Section 3 elicits information with regard to the library anxiety construct using a Malay Version of Bostick's (1992) Library Anxiety Scale (LAS). This scale consists of 46 items, anchored on a five-point Likert scale ranging from 1 (strongly disagree) to 5 (strongly agree). The scale comprises missing items negatively worded item were reversed scored to ensure high scores on each of the 46-item instrument to represent high level of anxiety whilst low scores would represent lower level of library anxiety.

The target population for this study was Bachelor of Medicine, Bachelor of Surgery (MBBS) at private University College Library. The sampling processes are; first, the target population for this study was 423 students pursuing their MBBS Degree. Second, after allowing for a plus/ minus five (5) percent error rate, one hundred and thirty (130) students were proportionately and randomly selected to participate in the study. Third, the participants were randomly selected using a table of computer generated random numbers by employing the Statistical Product Services and Solutions (SPSS) software. The instruments were administered to students during classroom hours. Instructors' permissions were obtained prior to the distribution of the questionnaires during classroom hours. One hundred percent $(100 \%)$ respond rate was achieved resulting in 130 fully completed usable questionnaires. The findings are based on responses from these 130 usable questionnaires. 


\section{Construct validity}

To assess the construct validity of a Malay version of Bostick's (1992) Library Anxiety Scale (LAS), an exploratory factor analysis using principal component analysis as the method of extracting components was performed on the 46-item instrument. Using a Varimax rotation and a factor loading coefficient at 0.40 or greater as a criterion for deeming a factor loading as practically significant resulted in a 14-factor solution that explained 70.8 percent of the variance in the library anxiety construct.

Out of the 46 -items that were submitted to a test of construct validity, only 44 items were found to have loaded on the 14 factors (each factor having an eigenvalue more than 1.00). Two items did not load on any of these 14 factors since they had factor loading coefficients that were below 0.40 . The results of running a principal component analysis also revealed that the bulk of the items (52\%) were loaded on the first factor while the remaining factors were each found to have between 1 to 3 items loaded on them. A meaningful interpretation of the factor becomes a difficult task. Consequently, it was decided to submit the 44 items to a second run of the principal component analysis.

The second run of the principal component analysis also employed a factor loading coefficient of 0.40 as practically significant. In addition to this criterion, it was also decided to force the 44 items into 7-factors to enable a more meaningful interpretation of the items underlying each of the factors. The second run of the principal component analysis resulted in a 7-factor solution that explained 51.3 percent of the variance in the library anxiety construct. This second run of the principal component analysis further reduced the number of items from 44 to 41 items. Though factors 1 through 5 each has more than 4 items loaded on them, factors 6 and 7 have only 2 items loaded on them. The situation is far from satisfactory. Consequently, it was decided to perform another round of principal component analysis to enable a more meaningful interpretation of the items underlying each of the factors.

The 41 items were submitted to third run of principal component analysis. This time around the items were forced into 5 factors using the previous criterion as a cut-off point to retain items that are being loaded onto a factor. The third round of principal component analysis resulted in a 5 -factor solution which explained 43.3 percent of the variance in the library anxiety construct. The findings revealed that the number of items is now reduced from 41 items to 37 items is spread more evenly among the 5 factors. However, factor 5 has only 3 items loaded onto it. In order to increase the number of items subsumed under each factor, the fourth round of principal component analysis was performed on the 37 items.

The fourth run of principal component analysis was carried out by forcing the items into 4 factors and by employing the previous criterion of 0.40 or more for a factor loading to be considered as practically significant. This resulted in a 4-factor solution that explained 38.9 percent of the variance in the library anxiety construct. After deleting items that cross-load on other factors, the total number of items was reduced from 37 to 35 . These 35 items were loaded onto 4 factors. However, a meaningful interpretation of the items underlying each of the 4 factors was still unsatisfactory. Consequently, it was decided to submit the 35 items to a fifth run of the principal component analysis to enable a more meaningful interpretation of the items underlying each of the factors.

The 35 items were submitted to fifth run of principal component analysis. This time around the items was forced into 4 factors using the previous criterion as a cut-off point to retain 
items that are being loaded onto a factor. The fifth round of principal component analysis resulted in a 3-factor solution which explained 41.6 percent of the variance in the library anxiety construct. Number of item was reduced from 35 to 32 items. These 32 items loaded onto 3 factors. Table 1 describes the factors, number of items, the eigenvalue as well as the percent of variance explained by each factor.

Table 1: Description of three factors derived from the fifth run of principal component analysis.

\begin{tabular}{lccc}
\hline \multicolumn{1}{c}{ Factor Description } & No. of Items & Eigenvalue & $\begin{array}{c}\text { Percent of Variance } \\
\text { explained }\end{array}$ \\
\hline Barriers with services providers & 17 & 8.669 & 19.760 \\
\hline Affective barriers & 7 & 3.505 & 11.550 \\
\hline Comfort with Library technology & 8 & 2.384 & 10.282 \\
\hline
\end{tabular}

\section{RESULTS}

\section{Internal reliability}

The first factor component had 17 items underlying it. A detail examination of the 17 items showed that they were examining an underlying concept that can be labeled as Barriers with Services Providers. All the 17 items seem to indicate service providers as a source of a component or dimension of the library anxiety construct. Before a sub-scale called Barriers with Services Providers was computed, the 17 item component was submitted to an internal reliability assessment using Cronbach's internal reliability coefficient alpha. The results of running an internal reliability assessment test using Cronbach's alpha revealed the 17 item component to have yielded an alpha value of 0.89 which is above the recommended value of 0.70 as suggested by Nunnally (1978). The findings also showed that dropping any of the 17 items would not raise Cronbach's alpha value to anything higher than 0.89 . Subsequently all the 17 items were averaged to compute a composite variable called "Barriers with Services Providers". This composite variable is a sub-scale of the overall library anxiety scale. The findings with regard to the internal reliability assessment for the 17 item component are shown in Table 2.

The second factor component had 7 items underlying it. A detail examination of the 7 items showed that they were examining an underlying concept that can be labeled as Affective Barriers. All the 7 items seem to indicate affective barriers as a source of a component or dimension of the library anxiety construct. Before a sub-scale called Affective Barriers was computed, the 7 item component was submitted to an internal reliability assessment using Cronbach's internal reliability coefficient alpha. The results of running an internal reliability assessment test using Cronbach's alpha revealed the 7 item component to have yielded an alpha value of 0.80 which is above the recommended value of 0.70 as suggested by Nunnally (1978). The finding also showed that dropping any of the 7 items would not raise Cronbach's alpha value to anything higher than 0.80 . Subsequently all the 7 items were averaged to compute a composite variable called Affective Barriers. This composite variable is a sub-scale of the overall library anxiety scale. The findings with regard to the internal reliability assessment for the 7 item component are shown in Table 3. 
Table 2: Factor 1 - Barriers with Service Providers (Alpha $=0.89)$

\begin{tabular}{|c|c|c|}
\hline $\begin{array}{c}\text { Item } \\
\text { Number }\end{array}$ & Scale Items & $\begin{array}{r}\text { Factor } \\
\text { loadings }\end{array}$ \\
\hline Item 32 & $\left\{\begin{array}{l}\text { Kakitangan perpustakaan tidak mempunyai masa untuk menolong saya } \\
{[\text { Librarians don't have time to help me] }}\end{array}\right.$ & 0.887 \\
\hline Item 33 & $\begin{array}{l}\text { Peraturan perpustakaan sangat ketat } \\
\text { [The library's rules are too restrictive] }\end{array}$ & 0.889 \\
\hline Item 34 & $\begin{array}{l}\text { Arahan penggunaan komputer tidak begitu jelas } \\
\text { [The directions for using the computers are not clear] }\end{array}$ & 0.889 \\
\hline Item 36 & $\left\{\begin{array}{l}\text { Kakitangan perpustakaan tidak mempedulikan rungutan pelajar } \\
\text { [The library staff doesn't listen to students] }\end{array}\right.$ & 0.889 \\
\hline Item 43 & $\begin{array}{l}\text { Kakitangan perpustakaan tidak mempunyai masa untuk membantu } \\
\text { pelajar kerana sering menggunakan telefon } \\
\text { [The librarians don't have time to help me because they are always on } \\
\text { the telephone] }\end{array}$ & 0.888 \\
\hline Item 35 & $\begin{array}{l}\text { Saya tidak tahu sumber apa yang ada di Perpustakaan } \\
\text { [I don't know what resources are available in the library] }\end{array}$ & 0.889 \\
\hline Item 50 & $\begin{array}{l}\text { Kebiasaannya tidak ada sesiapa di perpustakaan boleh membantu saya } \\
\text { [There is often no one available in the library to help me] }\end{array}$ & 0.890 \\
\hline Item 44 & $\begin{array}{l}\text { Kakitangan perpustakaan tidak mempunyai masa untuk membantu } \\
\text { pelajar kerana sering sibuk melakukan tugasan lain. } \\
\text { [The librarians don't have time to help me because they are always } \\
\text { doing something else] }\end{array}$ & 0.889 \\
\hline Item 28 & $\begin{array}{l}\text { Kakitangan perpustakaan tidak mengambil peduli tentang pelajar } \\
\text { [The staff doesn't care about students] }\end{array}$ & 0.889 \\
\hline Item 30 & $\begin{array}{l}\text { Saya tidak faham bagaimana perpustakaan mengenakan denda bagi } \\
\text { pulangan bahan yang tidak melebihi had masa } \\
\text { [I don't understand the library's overdue fines] }\end{array}$ & 0.893 \\
\hline Item 27 & $\begin{array}{l}\text { Saya tidak dapat mencari maklumat yang saya perlukan di } \\
\text { perpustakaan } \\
{[\text { [ can't find information that I need in the library] }}\end{array}$ & 0.890 \\
\hline Item 42 & $\begin{array}{l}\text { Kakitangan perpustakaan tidak mempunyai masa untuk membantu } \\
\text { pelajar } \\
\text { [Library staffs don't have time to help me] }\end{array}$ & 0.889 \\
\hline Item 26 & $\begin{array}{l}\text { Perpustakaan tidak pernah ada bahan yang saya perlukan } \\
\text { [The library never has the materials that I need] }\end{array}$ & 0.891 \\
\hline Item 47 & $\begin{array}{l}\text { Saya tidak tahu tindakan selanjutnya apabila buku yang dikehendaki } \\
\text { tidak ada di rak } \\
\text { [I don't know what to do next when the book I need is not on the shelf ] }\end{array}$ & 0.892 \\
\hline Item 41 & $\begin{array}{l}\text { Kakitangan perpustakaan selalu membantu pelajar } \\
\text { [The librarians are helpful] }\end{array}$ & 0.895 \\
\hline Item 38 & $\begin{array}{l}\text { Saya sering tidak dapat tempat duduk di Perpustakaan } \\
\text { [l often can't find a place to study in the library] }\end{array}$ & 0.895 \\
\hline Item 55 & $\begin{array}{l}\text { Kakitangan perpustakaan tidak mesra pengguna } \\
{[\text { The librarians are unfriendly] }}\end{array}$ & 0.894 \\
\hline
\end{tabular}


Karim, N.H.A \& Rashid, N.R.A.

Table 3: Factor 2 - Affective barriers (Alpha $=0.80)$

\begin{tabular}{|c|c|c|}
\hline $\begin{array}{l}\text { Item } \\
\text { Number }\end{array}$ & Scale Items & $\begin{array}{c}\text { Factor } \\
\text { loadings }\end{array}$ \\
\hline Item 54 & $\begin{array}{l}\text { Saya boleh menanya mana-mana kakitangan perpustakaan sekiranya } \\
\text { saya tidak mahir menggunakan sesuatu alat/perkakasan } \\
{\left[\begin{array}{l}\text { I can always ask a librarian if I don't know how to use equipment in the } \\
\text { library] }\end{array}\right.}\end{array}$ & 0.759 \\
\hline Item 53 & $\begin{array}{l}\text { Perpustakaan adalah sangat penting dalam proses pembelajaran saya } \\
\text { [The library is important part of my undergraduate studies] }\end{array}$ & 0.745 \\
\hline Item 51 & $\begin{array}{l}\text { Saya rasa selesa berada di perpustakaan } \\
\text { [l feel comfortable in the library] }\end{array}$ & 0.741 \\
\hline Item 25 & $\begin{array}{l}\text { Perpustakaan adalah tempat yang selesa untuk belajar } \\
\text { [The library is a comfortable place to study] }\end{array}$ & 0.739 \\
\hline Item 49 & $\begin{array}{l}\text { Saya gembira belajar perkara baru tentang perpustakaan } \\
\text { [l enjoy learning new things about the library] }\end{array}$ & 0.766 \\
\hline Item 46 & $\begin{array}{l}\text { Saya merasa keliru ketika berada di perpustakaan } \\
\text { [I get confused trying to find my way around the library] }\end{array}$ & 0.749 \\
\hline Item 12 & $\begin{array}{l}\text { Saya tidak boleh mendapatkan bantuan di perpustakaan apabila ianya } \\
\text { diperlukan } \\
\text { [l can't get help in the library at the time I need it] }\end{array}$ & 0.786 \\
\hline
\end{tabular}

The third factor component had 8 items underlying it. A detail examination of the 8 items showed that they were examining an underlying concept that can be labeled as Comfort with Library Technology. All the 8 items seem to indicate comfort with library technology as a source of a component or dimension of the library anxiety construct. Before a subscale called Comfort with Library Technology was computed, the 8 item component was submitted to an internal reliability assessment using Cronbach's internal reliability coefficient alpha. The results of running an internal reliability assessment test using Cronbach's alpha revealed the 8-item component to have yielded an alpha value of 0.72 which is above the recommended value of 0.70 as suggested by Nunnally (1978). The findings also showed that dropping any of the 8 items would not raise Cronbach's alpha value to anything higher than 0.72 . Subsequently all the 8 items were averaged to compute a composite variable called "Comfort with Library Technology". This composite variable is a sub-scale of the overall library anxiety scale. The findings with regard to the internal reliability assessment for the 8 item component are shown in Table 4.

Table 4: Factor 3 - Comfort with library technology (Alpha $=0.72)$

\begin{tabular}{|c|c|c|}
\hline $\begin{array}{l}\text { Item } \\
\text { Number }\end{array}$ & Scale Items & $\begin{array}{c}\text { Factor } \\
\text { loadings }\end{array}$ \\
\hline Item 13 & $\begin{array}{l}\text { Katalog perpustakaan dalam talian (OPAC) mudah Digunakan } \\
\text { [The library catalogue (OPAC) is easy to use] }\end{array}$ & 0.670 \\
\hline Item 14 & $\begin{array}{l}\text { Saya selalu menggunakan katalog perpustakaan dalam talian (OPAC) } \\
\text { sebelum ke rak buku } \\
\text { [l always use the library catalogoe (OPAC) before approaching the } \\
\text { shelves ] }\end{array}$ & 0.695 \\
\hline Item 16 & $\begin{array}{l}\text { Saya selalu menggunakan pangkalan data dalam talian apabila ingin } \\
\text { mencari maklumat } \\
\text { [l always use online databases when I'm looking for information] }\end{array}$ & 0.682 \\
\hline
\end{tabular}




\begin{tabular}{c|l||c}
\hline \hline Item 17 & $\begin{array}{l}\text { Saya tidak tahu cara menggunakan perkhidmatan digital } \\
\text { [I don't know how to use digital services] }\end{array}$ & 0.681 \\
\hline \hline Item 39 & $\begin{array}{l}\text { Perkhidmatan internet di perpustakaan sangat perlahan } \\
{[\text { The internet services in the library are too slow] }}\end{array}$ & 0.690 \\
\hline \hline Item 40 & $\begin{array}{l}\text { Perkhidmatan internet boleh digunakan bila-bila sahaja } \\
{[\text { The internet services are always accessible when I want to use them ] }}\end{array}$ & 0.715 \\
\hline \hline Item 24 & $\begin{array}{l}\text { Saya sering menggunakan self-check machine bagi proses pinjaman buku } \\
{[\text { l frequently use self check machine to borrow items from the library] }}\end{array}$ & 0.723 \\
\hline \hline Item 45 & $\begin{array}{l}\text { Saya tidak pasti bagaimana hendak memulakan sesuatu kajian itu } \\
{[\text { I'm unsure about how to begin my research] }}\end{array}$ & 0.696 \\
\hline \hline
\end{tabular}

\section{DISCUSSION}

The purpose of the study was to evaluate the psychometric soundness of a Malay language version of Sharon L. Bostick's multidimensional Library Anxiety Scale among medical undergraduate students in a private Malaysian institution of higher learning. Of the 46 items that were used to assess the library anxiety phenomenon, only 32 items were found to have loaded on 3 interpretable factors. Hence, the findings resulted in a 3 -factor solution with the following sub-scales: barriers with service providers (17 items), affective barriers ( 7 items) and comfort with library technology ( 8 items).

Each of 3 sub-scales was subsequently examined for internal reliability and was found to have met the criterion of 0.70 as recommended by Nunnally and Bernstein (1994). Further, each of the items in the 3 sub-scales was found to correlate significantly (at $p<.01$ ) with the total score of the respective sub-scales. The correlation coefficients for each of the item in the respective sub-scales reflect the factor loading coefficients that were yielded as a result as of running a principal component exploratory factor analysis. Hence, efforts to triangulate the findings on construct validation for the Malay language version of the Bostick's (1992) Library Anxiety Scale using item to total score correlation was successful.

The results of testing the soundness of a Malay language version of Bostick's (1992) multidimensional Library Anxiety Scale are somewhat consistent with previous empirical efforts to psychometrically evaluate the scales construct validity and internal reliability. Bostick's pioneering psychometric effort in developing a multidimensional Library Anxiety Scale resulted in a 5 -factor solution that collectively explained $51.8 \%$ of the total variance in the library anxiety constructs. The present study resulted in a 3-factor solution which explained only $41.6 \%$ of the variance in the library anxiety construct. Hence, the Malay language version partially supports that of Bostick's (1992) original study in that only 3 of the original sub-scales are supported in this study: barriers with service providers, affective barriers and comfort with library technology. While previous psychometric efforts to evaluate Bostick's (1992) multidimensional Library Anxiety Scale resulted in more than 4factor solutions, this present study resulted in a 3-factor solution. The difference lies in the fact that the majority of these studies (Noor and Ansari 2010; Van Kampen 2004 and Anwar; Al-Kandari and Al-Qallaf 2004) were modified English language version of Bostick's (1992) scale. The present study however was the first study to have employed a Malay language version of the Bostick's (1992) Library Anxiety Scale. Hence, it is not surprising that the findings revealed a 3-factor solution instead of a 5 -factor solution (Noor and Ansari 2010), a 6-factor solution (Van Kampen 2004) and a 4-factor solution (Anwar, AlKandari and Al-Qallaf 2004). Shoham and Mizrachi (2001) was the only study that employed a non-English language version of Bostick's (1992) scale that resulted in a 7factor solution called Hebrew-LAS. 
The present study is perhaps the only psychometric appraisal of Bostick's (1992) Library Anxiety Scale that resulted in the most number of items for the sub-scale barriers with staff. It has 17 items subsumed under the sub-scale called barriers with service providers. This finding lends incremental validity to the previous psychometric efforts in appraising Bostick's (1992) Library Anxiety Scale in that it too also yielded a similar sub-scale but with a greater number of items subsumed under it. It is also consistent with previous findings in that the sub-scale, barriers with service providers also yielded an internal reliability coefficient alpha value of more than 0.70 .

The findings with regard to the second sub-scale, affective barriers, is consistent with previous psychometric appraisals of Bostick's (1992) library anxiety construct. This Malay Language version of Bostick's (1992) Library Anxiety Scale also yielded a subscale not unlike previous psychometric appraisal efforts such as those by Van Kampen (2004), Noor and Ansari (2010) and Swigon (2011). Additionally, the sub-scale affective barriers yielded an internal reliability coefficient alpha value of more than 0.70 . Thus, the findings with regard to this sub-scale lend incremental validity to previous psychometric assessments of Bostick's (1992) multidimensional library anxiety scale.

The third sub-scale yielded by the Malay language version of Bostick's (1992) Library Anxiety Scale was comfort with library technology. The findings with regard to the third sub-scale of a Malay language version of Bostick's (1992) Library Anxiety Scale is consistent with previous empirical efforts to evaluate the psychometric soundness of Bostick's (1992) Library Anxiety Scale. The findings support that of Bostick's (1992) previous psychometric effort that produced a sub-scale called mechanical barriers. It also supports that of Noor and Ansari (2010) whose's psychometric evaluation of a modified version of Bostick's (1992) Library Anxiety Scale also yielded a sub-scale called comfort with library technology. Further the findings with regard to the sub-scales also support that of Van Kampen (2004) and Swigon (2011). Additionally, the sub-scale 'comfort with library technology' also yielded an internal reliability coefficient alpha value of more than 0.70 which is consistent with previous studies (Bostick 1992; Van Kampen 2004; Noor and Ansari 2010; Swigon 2011).

\section{CONCLUSION}

The present study is probably the first attempt to empirically validate a Malay language version of Bostick's (1992) Library Anxiety Scale. The findings with regards to the psychometric properties of the Malay translated version of the Library Anxiety Scale somewhat supports previous validation efforts to cross-culturally assess the scale among non-native speakers of English. However, unlike previous cross-cultural validation efforts, this study employed a modified but translated Malay version of the scale which resulted in 3 -factor solution. Hence, instead of a 4 or 5 -factor solution, the present study yielded a 3factor solution with the following sub-scales: barriers with service providers, affective barriers and comfort with library technology. Despite the reduction in number of sub-scales from Bostick's (1992) 5 sub-scales to only 3 of the original sub-scales, the sub-scales were found to be internally reliable. Hence it is tentatively concluded that despite the fewer number of sub-scales that was produced, the Malay language version of Bostick's (1992) Library Anxiety Scale in still a valid and reliable instrument. Psychometrically the scale has been shown to be a sound instrument. 
We recommend more research be conducted to cross-culturally assess the Malay version of Bostick's (1992) Library Anxiety Scale across a spectrum of university library users since such efforts would lend incremental validity to the aforesaid instrument.

\section{ACKNOWLEDGEMENT}

This research received no specific grant from any funding agency in the public, commercial, or not-for-profit sectors.

\section{REFERENCES}

Anwar, M.A., Kandari, N.M. and Al-Qallaf, C.L. 2004. Use of Bostick's library anxiety scale on undergraduate biological science students of Kuwait University. Library and Information Science Research, Vol.26, no.3: 266-283.

Bostick, S. I. 1992. The development and validation of the library anxiety scale. (Unpublished doctoral dissertation). Wayne State University.

Jiao, Q.G., Onwuegbuzie, A.J. and Lichenstein, A.A. 1996. Library anxiety: characteristics of at-risk college students. Library and Information Science Research, Vol.18, no.2: 151163.

Jiao, Q.G. and Onwuegbuzie, A.J. 1999a. Identifying library anxiety through students'learning-modality preferences. Library Quarterly, Vol.69, no.2: 202-216.

Jiao, Q.G., Onwuegbuzie, A.J., and Bostick, S.L. 2004. Racial differences in library anxiety among graduate students. Library Review, Vol.53, no.4: 228-235.

Mellon, C.A. 1986. Library anxiety : A grounded theory and its development. College and Research Libraries, Vol.47, no.2: 160-165.

Noor, H.A.K. and Ansari, N. 2010. A cross-cultural evaluation of Bostick's (1992) Library Anxiety scale: Investigating the scale's psychometric properties in a Malaysian university library environment. Malaysian Journal of Library and Information Science, Vol.15, no.1: 115-134.

Nunnally J.C. 1978. Psychometric theory. New York : McGraw-Hill

Shoham, S. and Mirzachi, D. 2001 . Library anxiety among undergraduates : a study of Israeli B. Ed. Students. Journal of Academic Librarianship, Vol.27, no. 4: 305-309.

Swigon, M. 2011. Library anxiety among Polish students : Development and validation of the Polish Library Anxiety Scale. Library \& Information Science Research, Vol. 33, no.2: 144-150.

Van Kampen, D.J. 2004. Development and validation of the multidimensional library anxiety scale. College and Research Libraries, Vol.65, no.1:, 28-34. 